\title{
Pengaruh ISO 9001: 2015, motivasi, dan kompetensi terhadap kinerja pustakawan di Perpustakaan Universitas Hasanuddin
}

\author{
Chusnul Chatimah Asmad1, Abdul Rahman Rahim², Andi Jam'an ${ }^{3}$ \\ 1Universitas Islam Negeri Alauddin Makassar \\ Jl. H. M. Yasin Limpo No. 36, Samata, Gowa, Sulawesi Selatan, 92113 \\ 2,3Universitas Muhammadiyah Makassar \\ Jl. Sultan Alauddin No. 259, Talasalapang, Makassar, Sulawesi Selatan, 90221 \\ Email: ${ }^{1}$ chusnulchatimah.a@uin-alauddin.ac.id, 2a.rrahim@unismuh.ac.id, 3andi.jam'an@unismuh.ac.id
}

Received: April 2019; Accepted: November 2019; Published: December 2019

\begin{abstract}
Motivation and competence can be variables that affect the level of librarian performance. ISO 9001: 2015 can also affect librarian performance as there is a quality management system clause that focuses on human resources in the organization. Therefore, the purpose of this research was to find out and analyze the influence of ISO 9001: 2015, motivation, and competence partially and simultaneously on the performance of librarians in the UNHAS Library. This study used quantitative survey research, with a total population of 42 people. The sample was the entire population. The results showed that motivation and competence partially had a significant effect on the performance of librarians. This is consistent with the opinions of several experts and relevant studies. Furthermore, ISO 9001: 2015 did not have a significant partial effect. These findings indicated that ISO in the UNHAS Library could not reach the realm of librarian performance improvement, one of which was due to the lack of librarian understanding of commitment and quality policy in ISO 9001: 2015. Based on the $f$ test, it discovered that simultaneously, all independent variables had a significant effect on the dependent variable of 53,863. In conclusion, based on the regression test, it finds out ISO 9001: 2015 has no partial effect; however, it is simultaneous when integrated with motivation and competence variables, whereas motivation and competence variables can partially influence the performance of the UNHAS Library librarian.
\end{abstract}

Keywords: ISO 9001: 2015; Competence; Motivation; Librarian performance

\begin{abstract}
Abstrak
Motivasi dan kompetensi dapat menjadi variabel yang memengaruhi tingkat kinerja pustakawan. Selain itu, ISO 9001:2015 juga dapat memberikan pengaruh terhadap kinerja pustakawan karena di dalamnya terdapat klausul sistem manajemen mutu yang berfokus pada sumber daya manusia dalam organisasi. Oleh karena itu, tujuan penelitian ini yaitu untuk mengetahui pengaruh ISO 9001: 2015, motivasi, dan kompetensi secara parsial dan simultan terhadap kinerja pustakawan di Perpustakaan UNHAS. Penelitian ini menggunakan metode penelitian survei kuantitatif. Jumlah populasi 42 orang dengan sampel yakni seluruh jumlah populasi yang ada. Hasil penelitian menunjukkan bahwa ISO di Perpustakaan UNHAS belum dapat menjangkau ranah peningkatan kinerja pustakawan yang salah satunya disebabkan kurangnya pemahaman pustakawan akan komitmen dan kebijakan mutu dalam ISO 9001:2015. Berdasarkan uji $f$, diperoleh bahwa secara simultan semua variabel bebas berpengaruh signifikan terhadap variabel terikat sebesar 53.863. Berdasarkan uji regresi tersebut, maka dapat dinyatakan bahwa ISO 9001:2015 tidak berpengaruh secara parsial namun simultan apabila diintegrasikan dengan variabel motivasi dan kompetensi. Sementara variabel motivasi dan kompetensi dapat berpengaruh secara parsial terhadap kinerja pustakawan Perpustakaan UNHAS. Adapun simpulan menunjukkan motivasi dan kompetensi secara parsial berpengaruh signifikan terhadap kinerja pustakawan. Hal tersebut sesuai dengan pendapat beberapa ahli dan kajian penelitian yang relevan. Selanjutnya, ISO 9001:2015 tidak berpengaruh signifikan secara parsial.
\end{abstract}

Kata kunci: ISO 9001:2015; Kompetensi; Motivasi; Kinerja pustakawan 


\section{PENDAHULUAN}

Era globalisasi menuntut setiap perguruan tinggi agar bersikap terbuka dan transparan terhadap perubahan perkembangan teknologi informasi. Salah satu upaya yang dapat dilakukan perguruan tinggi adalah memberikan perhatian lebih dan orientasi penuh terhadap perpustakaan. Hal itu dikarenakan perpustakaan berperan penting sebagai server utama yang mengatur penyebaran informasi dan perkembangan knowledge management melalui proses belajar mengajar, demi mewujudkan tri dharma perguruan tinggi (Indrasari, 2013).

Perpustakaan perguruan tinggi merupakan lembaga penyedia informasi yang sepatutnya memberikan berbagai layanan informasi yang berorientasi terhadap kebutuhan pemustaka (Nurjannah, 2016). Layanan menjadi tujuan utama dari serangkaian pelaksanaan kegiatan yang diselenggarakan dalam perpustakaan dan pustakawan menjadi ujung tombak pelaksanaan tujuan tersebut (Mayora \& Nelisa, 2013). Oleh karena itu, dedikasi yang tinggi dari pustakawan sangat diperlukan demi menunjang terlaksananya layanan yang bermutu, user oriented, bernilai guna, dan berkarakter prima sehingga dapat memenuhi dan memuaskan kebutuhan setiap pemustaka.

Penerapan standardisasi perpustakaan merupakan suatu langkah praktis yang dapat dilakukan dalam meningkatkan kualitas kerja pustakawan. Standardisasi tersebut harus dipenuhi agar perpustakaan perguruan tinggi dapat dikelola dengan baik (Hs, 2009). Salah satu standardisasi yang memiliki tujuan dan fokus utama terhadap kualitas atau mutu adalah Sistem Manajemen Mutu (SMM)
International Standar Organization (ISO) (Umiyati, 2015).

Perpustakaan yang menerapkan ISO akan memiliki kebijakan mutu atau berkomitmen terhadap mutu. Setiap pekerjaan yang dilaksanakan akan didasarkan pada sasaran mutu yang ada. Pada saat semua unsur perpustakaan sudah diproses sesuai mutu, maka kualitas kerja pustakawan akan semakin mengalami kemajuan dari waktu ke waktu. Apabila kinerja pustakawan meningkat, maka eksistensi perpustakaan sebagai portal informasi yang kredibel akan tetap terjaga (Asmad \& Mathar, 2015).

Penelitian terkait ISO telah banyak dilakukan, mulai dari SMM ISO 9001:2001 hingga 9001:2015. Penelitian tersebut di antaranya menjadikan sumber daya manusia sebagai objek penelitian, terutama menyangkut kinerja. Beberapa penelitian tersebut telah menemukan bahwa ISO berpengaruh terhadap kinerja organisasi seperti dalam penelitian Rahmawaty (2014). Hasil penelitian tersebut menunjukkan bahwa ISO berpengaruh terhadap kinerja Fakultas Ilmu Sosial dan Ekonomi Universitas Negeri Yogyakarta. Adapun Penelitian Astuti and Ati (2015) menunjukkan hasil pengaruh ISO terhadap kinerja sumber daya manusia. Penerapan ISO merupakan langkah yang bermanfaat dalam meningkatkan kinerja pustakawan.

Faktor lain selain ISO yang dapat menjadi potensi untuk memengaruhi kinerja pustakawan adalah motivasi. Menurut Daft (2012), motivasi adalah, "Kekuatan ekstrinsik dan intrinsik yang dimiliki seseorang untuk membangkitkan semangat kerja dan ketekunan yang berkesinambungan demi mencapai sesuatu yang diinginkan." Oleh karena itu, 
kepala perpustakaan terutama pada perguruan tinggi harus mampu memberikan motivasi kepada para pustakawan demi menunjang tercapainya tri dharma perguruan tinggi serta visi dan misi dari perpustakaan tersebut (Alfatih \& Wijayanti, 2018).

Pustakawan yang memiliki motivasi rendah harus diberi perhatian lebih dan stimulus agar dorongan untuk bekerja meningkat dan dapat dipertahankan. Hal ini yang melatarbelakangi pentingnya penelitian motivasi, yaitu sebagai alat ukur mengetahui tingkat motivasi yang dimiliki pustakawan dan pengaruhnya terhadap performa atau kualitas kerjanya (Risparyanto, 2017).

Kompetensi sebagai keterampilan atau pengetahuan yang dimiliki pustakawan dalam bekerja. Serta pustakawan memiliki perilaku dalam bertugas, untuk mencapai tujuan sebagai pedoman dalam mengemban tugas dan kewajiban (Azmar, 2015). Menurut Diyah and Permana (2012), kompetensi yang dimiliki pustakawan menyangkut kemampuan, keterampilan, dan karakteristik kerja dalam melakukan setiap pekerjaan agar berjalan efektif dan efisien. Oleh karena itu, kompetensi sepatutnya dimiliki, dipertahankan, dan ditingkatkan pustakawan agar tugas dan kewajiban yang ada dapat berjalan dengan baik, tepat sasaran, dan sesuai dengan tujuan yang ingin dicapai.

Peningkatan kompetensi diperlukan pustakawan agar mampu bekerja dan bertahan di segala bidang layanan perpustakaan dan mampu memberikan hasil kerja yang optimal (Nashihuddin \& Aulianto, 2015). Merujuk hal tersebut, maka kompetensi perlu diteliti agar dapat menjadi bahan evaluasi kepala perpustakaan demi mempertahankan atau meningkatkan kompetensi para pustakawan, sehingga kinerja mereka tetap terkontrol dengan baik. Dengan demikian, kompetensi menjadi salah satu landasan untuk meningkatkan kinerja demi memenuhi keinginan para pemustaka (Husna, 2018).

Perpustakaan Universitas Hasanuddin menjadi satu di antara puluhan perpustakaan perguruan tinggi yang menerapkan ISO mulai tahun 2014 sampai sekarang. ISO yang diterapkan adalah versi terbaru yaitu ISO 9001:2015. Namun selama penerapannya, para pemustaka masih mendapati pustakawan kurang memberikan pelayanan sesuai dengan kebutuhan mereka. Padahal sasaran ISO berfokus pada kepuasan pelanggan. Pada bagian sirkulasi, pustakawan kurang memberikan pelayanan prima seperti senyum, sapa, salam, sopan, dan santun.

Sementara itu, ada beberapa pegawai yang didapati kurang disiplin dalam bekerja. Boleh jadi, terdapat beban kerja yang menyebabkan pustakawan kurang memiliki dorongan kuat dalam melakukan pekerjaannya. Padahal motivasi berpengaruh dominan terhadap kinerja pustakawan (Jamaluddin, 2015).

Selain itu, proses temu balik informasi kadang kala mengalami hambatan. Hal ini sesuai kajian terdahulu yang telah diteliti Sampe (2014), yang menyatakan bahwa kondisi tersebut masih terjadi di Perpustakaan Universitas Hasanuddin, di mana seharusnya kompetensi mereka di tingkatkan agar kinerja yang dihasilkan juga meningkat.

Berdasarkan tinjauan penelitian sebelumnya tersebut dan kondisi yang terlihat saat ini, maka perlu pembaharuan penelitian mengenai ISO 9001:2015 sebagai variabel terbaru. Hal ini bertujuan untuk mengetahui lebih jauh pengaruh secara parsial dan simultan ISO 9001: 2015, 
motivasi serta kompetensi terhadap kinerja pustakawan di Perpustakaan Universitas Hasanuddin Makassar, dan menganalisis lebih dalam integrasi dan hubungan di antara ke empat topik penelitian tersebut.

\section{METODE PENELITIAN}

Metode survei merupakan jenis penelitian yang digunakan dalam mengumpulkan data di lapangan sebagai upaya untuk mengetahui dan menganalisis topik permasalahan yang dikaji. Survei merupakan sebuah metode pengumpulan data yang ditujukan untuk mengevaluasi objek penelitian yang diteliti (Muhammad, Komariah, \& Kurniasih, 2019).

Berdasarkan tingkat uraiannya, penelitian ini termasuk dalam penelitian asosiatif yang menggambarkan hubungan dua variabel atau lebih dalam satu model regresi (Abdullah \& Sutanto, 2015).

Penelitian ini berdasarkan jumlah populasinya menggunakan teknik sampling sensus karena populasi relatif kecil atau dapat dijangkau penelitian, sehingga semua populasi dijadikan sampel penelitian (Fatma, Damayani, \& Rusmana, 2016). Semua anggota populasi dalam penelitian ini merupakan keseluruhan sampel. Namun demikian, dari 42 sampel tersebut terdapat 34 pustakawan yang menjadi responden utama dengan 8 staf tata usaha sebagai responden pendukung karena mereka mengetahui perkembangan kinerja pustakawan, motivasi, kompetensi dan mereka terlibat dalam SMM ISO 9001:2015. Selanjutnya, untuk melengkapi hasil penelitian yang ada, maka pemustaka Perpustakaan Universitas Hasanuddin dijadikan sebagai informan.

Pengumpulan data dilakukan menggunakan kuesioner berupa angket tertutup dengan skala rasio sebagai range jawaban yang dimulai dengan pernyataan tidak setuju hingga sangat setuju. Teknik observasi, wawancara, dan dokumentasi juga digunakan demi menambah data yang dianggap kurang dan mendukung hasil penelitian yang diperoleh melalui kuesioner. Studi pustaka juga digunakan sebagai alternatif metode pengumpulan data untuk menguatkan temuan di lapangan, menggunakan dokumen yang berhubungan dengan subjek penelitian sebagai data yang akan dianalisis secara mendalam.

Selain itu, data yang telah diperoleh dianalisis menggunakan teknik kuantitatif dan statistik inferensial untuk menguji hipotesis melalui regresi berganda (Sugiyono, 2013). Data yang terkumpul dianalisis dalam model regresi linear berganda dan diolah melalui aplikasi SPSS versi 15. Namun sebelum itu, perlu dilakukan beberapa uji asumsi klasik di antaranya yaitu uji normalitas, heterokedastisitas, dan multikoliniearitas sebagai media identifikasi terhadap model regresi yang digunakan apakah sesuai dengan syarat asumsi klasik atau tidak (Ghozali, 2011). Setelah uji asumsi klasik, selanjutnya dilakukan uji $f$ atau uji simultan, uji parsial atau uji $t$, dan uji koefisien determinasi menggunakan nilai adjust square.

\section{HASIL DAN PEMBAHASAN}

Penelitian ini menyajikan karakteristik responden berdasarkan usia, gender, pendidikan, dan masa kerja. Berdasarkan data responden, diketahui bahwa responden penelitian ini pada umumnya perempuan yaitu sebanyak 19 orang atau $54 \%$. Rata-rata usia antara 38-55 tahun atau $83 \%$, pendidikan rata-rata strata satu sebanyak 22 orang atau 67\%, dan masa 
kerja mereka rata-rata $<20$ tahun yang berjumlah 18 orang atau $1 \%$.

Variabel ISO 9001:2015 dalam penelitian ini diukur melalui 6 indikator. Berdasarkan hasil pengukuran tersebut, berarti sebagian besar responden dalam penelitian ini menjawab setuju pada 16 item kuesioner dalam bentuk pernyataan terkait ISO 9001:2015 dengan jumlah persentase $58 \%$. Hal demikian menunjukkan bahwa ISO telah berjalan dengan baik meskipun ada sekitar 14\% yang menyatakan kurang setuju.

Berdasarkan uraian di atas, maka dapat dinyatakan bahwa sebagian besar menjawab setuju pada indikator evaluasi kinerja yaitu sebanyak 64\%. Hal ini menunjukkan bahwa evaluasi kinerja di Perpustakaan Universitas Hasanuddin berjalan dengan baik. Namun demikian, prinsip dari ISO itu sendiri sebagian besar menjawab kurang setuju pada indikator perbaikan terus menerus yaitu sebanyak $29 \%$ yang menunjukkan bahwa pustakawan masih ada yang belum mengilhami prinsip ISO dalam bekerja.

Variabel motivasi diukur menggunakan 5 indikator. Setiap indikator memiliki jumlah pernyataan yang bervariasi dan akhirnya menghasilkan karakteristik tanggapan responden yaitu bahwasanya tingkat persentase jawaban yang paling besar adalah setuju yaitu $47 \%$. Hal ini menunjukkan bahwa motivasi pustakawan bernilai baik sesuai dengan yang diinginkan meskipun ada sekitar $19 \%$ yang menyatakan motivasi pustakawan masih kurang.

Hasil interpretasi data menunjukkan bahwa responden menjawab setuju pada indikator penghargaan dengan tingkat persentase sebesar $54 \%$ dan aktualisasi diri sebesar 54\% juga. Berdasarkan interpretasi data di atas, maka dapat diasumsikan bahwa penghargaan dan aktualisasi yang diterima pustakawan bernilai baik, sehingga memengaruhi motivasi mereka dalam bekerja. Meski demikian, terdapat responden yang memberikan tanggapan kurang setuju terhadap indikator keamanan sebanyak $31 \%$ yang menunjukkan bahwa kondisi lingkungan kurang memotivasi pustakawan dalam bekerja.

Selanjutnya, peneliti menggunakan 5 indikator untuk mengukur kompetensi dalam penelitian ini. Maka, sesuai hasil penyebaran kuesioner, diperoleh jawaban responden terhadap 15 pernyataan terkait kompetensi. Sebagian besar responden menjawab kurang setuju yaitu 34\% dan $33 \%$ menjawab setuju. Hal ini terjadi karena banyaknya pernyataan negatif sehingga apabila dijumlahkan secara positif rata-rata responden menjawab setuju sebesar $55 \%$.

Berangkat dari analisis tersebut, maka kompetensi pustakawan dianggap bagus namun demikian tetap ada sekitar 24\% yang menjawab kurang setuju. Sesuai dengan pernyataan tersebut, maka sebagian besar responden menjawab kurang setuju pada indikator pengelolaan informasi sebanyak 49\%. Namun demikian, karena pernyataan pada indikator tersebut bernilai negatif sehingga pada hakikatnya menunjukkan bahwa pustakawan Universitas Hasanuddin pada dasarnya memiliki kemampuan dan keterampilan dalam mengolah informasi.

Selanjutnya, dalam penelitian ini terdapat 8 indikator yang menjadi alat ukur dalam variabel kinerja. Berdasarkan hasil tanggapan responden terhadap 15 pernyataan terkait kinerja pustakawan, sebagian besar menjawab kurang setuju yaitu 35\% dan 30\% menjawab setuju. Hal 
ini terjadi karena banyaknya pernyataan negatif, sehingga apabila dijumlahkan secara positif rata-rata responden menjawab setuju sebesar $54 \%$.

Data yang diperoleh menunjukkan bahwa kinerja pustakawan dianggap bagus namun demikian tetap ada sekitar $26 \%$ yang menjawab kurang setuju. Tingkat persentase paling tinggi terdapat pada indikator kesetiaan sebanyak $46 \%$. Ini berarti, pustakawan di Universitas Hasanuddin selama ini telah bekerja dengan menjunjung tinggi pekerjaan di atas segala-galanya.

Akan tetapi, terdapat $40 \%$ yang menyatakan kurang setuju pada indikator kerja sama. Hal ini berarti ada pustakawan yang tidak menjadikan kerja sama sebagai landasan kerja dan memilih bekerja sendiri. Padahal, pustakawan melalui kerja sama dapat menghasilkan pekerjaan yang berdaya guna tinggi.

Sesuai dengan hasil uji validitas yang telah diperoleh, maka dapat dikatakan bahwa semua item pernyataan yang mewakili variabel ISO 9001:2015 tidak ada yang memiliki kriteria $r_{\text {hitung }}<r_{\text {tabel }}(0,3044)$ sehingga dikatakan valid. Begitu pula halnya dengan variabel motivasi, kompetensi, dan kinerja pustakawan. Sementara untuk hasil uji reliabilitas, semua nilai cronbach's alpha tidak ada yang berada di bawah 0,60, sehingga dapat dikatakan kuesioner dalam penelitian ini bernilai reliabel karena tidak ada.

Selanjutnya, digunakan uji normalitas sebagai metode awal dari uji asumsi klasik dengan Kolmogorov-Smirnov sebagai teknik yang digunakan untuk memasukkan nilai residual variabel sehingga diperoleh nilai Asymp.Sig. (2-tailed) keseluruhan variabel sebesar 0,708>0,05. Oleh sebab itu, data dari populasi yang ada memenuhi syarat normalitas.

Uji asumsi klasik yang kedua yaitu uji multikolinearitas. Apabila tidak ditemukan gejala multikolinearitas, berarti model regresi penelitian ini bernilai baik. Adapun hasil uji multikolinearitas yang dilakukan melalui SPSS v15.

Tabel 1

Hasil uji multikolinearitas

\begin{tabular}{lcl}
\hline Variabel & Tolerance & VIF \\
\hline SMM_ISO & .804 & 1.244 \\
Motivasi & .289 & 3.460 \\
Kompetensi & .263 & 3.796 \\
\hline
\end{tabular}

Sumber: Hasil penelitian, 2017

Berdasarkan hasil uji mutikolinearitas, diperoleh nilai Tolerance semua variabel $>0,01$, sedangkan VIF semua variabel $<10$. Artinya, model regresi dalam penelitian ini bebas multikolinearitas.

Selanjutnya, model regresi yang baik juga ditentukan oleh ada tidaknya gejala auto korelasi pada saat mengolah data. Adapun dalam uji auto korelasi digunakan Durbin-Watson.

Tabel 2

Hasil uji auto korelasi

\begin{tabular}{lll}
\hline Model & $\begin{array}{l}\text { Adjusted R } \\
\text { square }\end{array}$ & $\begin{array}{l}\text { Durbin- } \\
\text { Watson }\end{array}$ \\
\hline 1 & .795 & 1.754 \\
\hline
\end{tabular}

Sumber: Hasil penelitian, 2017

Sesuai hasil uji auto korelasi di atas, diketahui nilai D 1.754. Berdasarkan uji Durbin Watson, diperoleh DW $>$ DU yaitu 1.754>1.6617 dan 4-DW > DU atau 2.246>1.6617. Sesuai dengan kaidah uji auto korelasi, maka tidak terjadi auto korelasi positif karena nilai Durbin Watson lebih besar dari nilai batas atas Durbin Watson dan tidak terjadi auto korelasi negatif karena 4-Nilai Durbin Watson lebih besar dari nilai batas atas Durbin Watson. Dengan kata lain, tidak 
ditemukan gejala auto korelasi dalam penelitian ini.

Uji asumsi klasik terakhir adalah heteroskedisitas. Uji gletser merupakan model yang digunakan dalam penelitian ini. Data yang diperoleh akan diolah berdasarkan SPSS v15 dan menghasilkan output seperti yang terlihat pada hasil uji heteroskedisitas.

Tabel 3

Hasil uji heteroskedisitas

\begin{tabular}{|c|c|c|}
\hline Variabel & $t$ & Sig. \\
\hline (Constant) & 3.060 & .004 \\
\hline ISO & -1.634 & .110 \\
\hline Motivasi & -1.581 & .122 \\
\hline Kompetensi & .265 & .793 \\
\hline
\end{tabular}

Nilai signifikansi variabel ISO 9001:2015 tabel 1.4. adalah 0.110, variabel motivasi 0,122, dan variabel kompetensi 0.793. Signifikansi dari semua variabel terhadap variabel kinerja pustakawan > 0,05 . Hal itu berarti, model regresi penelitian ini pada memenuhi seluruh uji asumsi klasik.

Setelah dilakukan uji asumsi klasik, maka data yang dikumpulkan selanjutnya dianalisis melalui uji $f$ untuk mengetahui pengaruh simultan atau pengaruh yang ditimbulkan seluruh variabel bebas secara bersama-sama terhadap variabel terikat. Dalam hal ini, diketahui nilai $f_{\text {tabel }}$ diperoleh dari tabel distribusi frekuensi $f$ sebesar 2,85. Sementara nilai $t_{\text {tabel }}$ diperoleh dengan menggunakan SPSS v15 dan mendapatkan hasil statistik pada hasil uji F.

Tabel 4

Hasil uji $F$

\begin{tabular}{lcl}
\hline Model & $\boldsymbol{F}$ & Sig. \\
\hline Regression & 53.863 & $.000(\mathrm{a})$ \\
Residual & & \\
Total & & \\
\hline
\end{tabular}

Sumber: Hasil penelitian, 2017

Sesuai dengan interpretasi data melalui tabel hasil uji $\mathrm{F}$, diperoleh bahwa $\mathrm{f}_{\text {hitung }}>$ dari $\mathrm{f}_{\text {tabel }}(57.243>2,85)$. Tingkat signifikansi diperoleh $0,000<0,05$, dengan kata lain hipotesis 4 di terima karena $\mathrm{h}_{0} \mathrm{di}$ tolak dan $\mathrm{h}_{\mathrm{a}}$ diterima.

Oleh karena itu, diperoleh hasil bahwa secara simultan variabel ISO 9001:2015, motivasi, kompetensi berpengaruh terhadap variabel kinerja pustakawan pada Perpustakaan Universitas Hasanuddin Makassar.

Penelitian ini memiliki tiga variabel bebas yang diuji $t$ dengan hipotesis 1 yaitu "ho: ISO 9001:2015 tidak berpengaruh secara signifikan terhadap kinerja pustakawan Perpustakaan Universitas Hasanuddin", dan " $h_{a}$ : ISO 9001:2015 berpengaruh secara signifikan terhadap kinerja pustakawan Perpustakaan Universitas Hasanuddin."

Hipotesis 2 yaitu " $h_{0}$ : motivasi tidak berpengaruh secara signifikan terhadap kinerja pustakawan Perpustakaan Universitas Hasanuddin", dan " $h$ : motivasi berpengaruh secara signifikan terhadap kinerja pustakawan Perpustakaan Universitas Hasanuddin."

Adapun hipotesis 3 yaitu " $h_{0}$ : kompetensi tidak berpengaruh secara signifikan terhadap kinerja pustakawan Perpustakaan Universitas Hasanuddin", dan " $h_{a}$ : kompetensi berpengaruh secara signifikan terhadap kinerja pustakawan Perpustakaan Universitas Hasanuddin."

Nilai thitung diperoleh melalui tabel distribusi $\mathrm{t}$ sebesar 2.024. Adapun nilai $t_{\text {hitung }}$ diperoleh menggunakan SPSS v15.

Tabel 5

Hasil uji T

\begin{tabular}{|c|c|c|c|}
\hline Variabel & $\begin{array}{l}\text { Un } \\
\text { standardized } \\
\text { coefficients }\end{array}$ & $\mathbf{t}$ & Sig. \\
\hline (Constant) & 6.337 & .676 & .503 \\
\hline ISO & .009 & .087 & .931 \\
\hline Motivasi & .300 & 2.415 & .021 \\
\hline Kompetensi & .586 & 4.483 & .000 \\
\hline
\end{tabular}


Tabel hasil uji $\mathrm{T}$ telah menunjukkan bahwa nilai $t_{\text {hitung }}$ variabel ISO 9001:2015 lebih kecil dari tabel $(-0.87<2.024)$, nilai

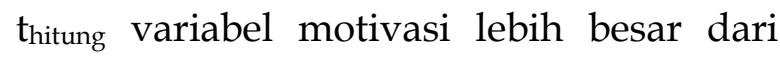
$t_{\text {tabel }}(2.415>2.024)$, sedangkan nilai thitung variabel kompetensi juga lebih besar dari $t_{\text {tabel }} \quad(4.483>2.024)$. Selain itu, nilai signifikansi variabel ISO 9001:2015 $0.931>0,05$.

Sementara nilai signifikan variabel motivasi yaitu $0.021<0.05$ dan kompetensi yaitu $0.00<0.05$. Berdasarkan data tersebut, maka variabel ISO 9001:2015 tidak memiliki pengaruh langsung atau parsial terhadap kinerja pustakawan, namun variabel lainnya yaitu motivasi dan kompetensi berpengaruh langsung terhadap tinggi rendahnya kinerja pustakawan Perpustakaan Universitas Hasanuddin Makassar.

Dengan kata lain, hipotesis 1 ditolak karena $h_{o}$ diterima dan $h_{a}$ ditolak, sehingga variabel ISO 9001:2015 tidak dapat berkontribusi langsung secara signifikan terhadap peningkatan atau rendahnya kinerja pustakawan. Hipotesis 2 diterima karena $h_{0}$ ditolak dan $h_{a}$ diterima, sehingga variabel motivasi dikatakan berpengaruh secara signifikan terhadap kinerja pustakawan. Hipotesis 3 diterima karena $h_{0}$ ditolak dan $h_{a}$ diterima, sehingga dapat dikatakan variabel kompetensi memberikan pengaruh secara signifikan terhadap kinerja pustakawan.

Model regresi yang baik adalah yang memberikan nilai koefisien determinasi yang tinggi. Untuk mengetahui hal tersebut maka diperoleh data seperti yang terdapat dalam hasil uji koefisien determinasi.

Pada tabel 6, diketahui bahwa nilai $\mathrm{r}$ square sebanyak 0,810 sementara nilai adjust square adalah 0.795 .
Tabel 6

Hasil uji koefisien determinasi

\begin{tabular}{llll}
\hline Model & $\begin{array}{l}\mathbf{R} \\
\text { Square }\end{array}$ & $\begin{array}{l}\text { Adjusted R } \\
\text { Square }\end{array}$ & $\begin{array}{l}\text { Std. Error } \\
\text { of the } \\
\text { Estimate }\end{array}$ \\
\hline 1 & .810 & .795 & 5.093 \\
\hline
\end{tabular}

Sumber: Hasil penelitian, 2017

Peneliti menggunakan adjust square dengan persentase $79,5 \%$ dalam penelitian ini sehingga dapat dikatakan bahwa variabel independen dalam penelitian ini memengaruhi variabel dependen sebanyak $79,5 \%$, adapun sisanya sebanyak 20,5\% dipengaruhi oleh variabel lainnya.

Tabel koefisien menunjukkan bahwa nilai koefisien regresi variabel ISO 9001:2015 adalah 0.009. Hal ini menunjukkan bahwa ISO 9001:2015 pengaruhnya hanya sedikit apabila dibandingkan dengan motivasi juga kompetensi. Motivasi memiliki nilai koefisien regresi sebesar 0.300 sehingga apabila motivasi meningkat maka kinerja pun akan meningkat. Sementara nilai koefisien regresi kompetensi adalah 0.586, sama dengan motivasi apabila kompetensi meningkat maka kinerja pun akan meningkat. Dengan demikian, persamaan regresi yang diperoleh berdasarkan hasil beta (unstandardized coefficients) adalah sebagai berikut: $\mathrm{Y}=6.337+0.009 \times 1+0,300 \times 2+0,586 \times 3$.

Berdasarkan hasil penelitian dan uji hipotesis yang telah dibahas sebelumnya, maka terbukti bahwa tidak terdapat pengaruh yang ditimbulkan ISO 9001:2015 terhadap kinerja pustakawan. Padahal teknik analisis data yang digunakan penelitian ini paling banyak digunakan terhadap penelitian pengaruh ISO 9001 dengan kinerja Sumber Daya Manusia (SDM) atau objek penelitian lainnya. Hal tersebut diketahui berdasarkan sebaran 
kajian penelitian pengaruh ISO 9001 terhadap kinerja SDM dan objek penelitian lainnya yang berjumlah 98 dalam berbagai bentuk seperti skripsi, tesis, dan jurnal. Selanjutnya, diperoleh hasil bahwa regresi linear berganda memiliki persentase sebanyak 28\% dari teknik analisis data lainnya sehingga dipercaya sebagai teknik analisis yang mampu menganalisis dan mengetahui pengaruh atau tidaknya ISO 9001: 2015 terhadap kinerja pustakawan.

Selanjutnya, hasil analisis deskriptif juga menandakan bahwa ISO 9001:2015 tidak menjadi faktor yang berpengaruh terhadap kinerja pustakawan. Namun demikian, hasil tersebut tidak dapat dijadikan sebagai rujukan utama penelitian kausalitas ini. Hal ini dilakukan apabila penelitian hanya berfokus pada penerapan SMM ISO 9001:2015, bukan pada pengaruhnya.

Sementara berdasarkan hasil observasi, ditemukan bahwa ISO 9001:2015 masih belum maksimal terealisasi, dikarenakan faktor utamanya adalah masih kurangnya sosialisasi dan makna dari sistem manajemen mutu. Hal itu sesuai data wawancara bahwa pegawai belum memahami kebijakan mutu dan prinsip manajemen mutu sesungguhnya. Adapun kebijakan mutu Perpustakaan Universitas Hasanuddin sesuai hasil dokumentasi yaitu mempunyai komitmen yang kuat untuk memuaskan kebutuhan semua costumer/stakeholder dengan mengimplementasikan ISO 9001:2015 melalui perbaikan berkelanjutan.

Apabila kebijakan mutu tidak terealisasi dengan baik, maka wajar jika ISO tidak memengaruhi kinerja pustakawan karena inti dari pelaksanaan ISO adalah dengan melaksanakan kebijakan mutu yang telah dibuat beserta target yang tertuang dalam sasaran mutu.
Selanjutnya, terdapat kesenjangan antara layanan dengan sasaran mutu. Apabila sasaran mutu telah disosialisasikan dengan baik, maka selayaknya mutu daripada layanan dapat bernilai baik pula.

Akan tetapi, target bukan ukuran sebab target bisa dicapai bisa juga tidak dan dengan diterapkannya ISO 9001:2015, maka target yang tidak tercapai akan dicari jalan keluarnya. Namun demikian, terkait apakah sasaran mutu telah berjalan dengan baik setelah dikomunikasikan masih perlu diteliti lebih jauh dengan hanya berfokus pada sasaran mutu, membandingkan data primer dan data sekunder seperti data keluhan pemustaka, agenda kegiatan otomasi dan dokumen lainnya.

Hasil wawancara juga menunjukkan bahwa arus lalu lintas temu balik informasi tidak berjalan dengan lancar dan pustakawan kurang memberikan umpan balik terhadap pemustaka. Hal tersebut dapat terjadi, karena kurangnya sumber daya manusia di perpustakaan sehingga hasil wawancara ini dapat menjadi alasan bahwa ISO 9001:2015 tidak berpengaruh terhadap kinerja pustakawan.

Oleh sebab itu, dapat dikatakan apabila ISO 9001:2015 meningkat maka kinerja pustakawan tidak akan meningkat. Selanjutnya, tidak berpengaruhnya variabel ISO 9001:2015 menunjukkan penelitian ini tidak dapat mendukung teori Gaspers yang berbunyi bahwa manfaat ISO bermanfaat bagi masyarakat dalam organisasi melalui peningkatan semangat kerja dan jaminan kestabilan dalam bekerja. Begitu pula dengan pandangan Levine and Michael (2010) yang mengemukakan bahwa standar ISO 9001 memberikan pengaruh cukup besar untuk tenaga kerja.

Kemudian berdasarkan penelitian 
sebelumnya, penelitian ini juga tidak sesuai dengan temuan Irsyada and Edwar (2013 yang berfokus pada indikator sumber daya manusia. Namun, dalam Levine, and Michael (2010) terjadi perbedaan indikator. Sementara, indikator dalam penelitian ini sama dengan indikator yang digunakan dalam penelitian Sindhuwinata and Felecia (2016) serta Supriyadi (2012). Akan tetapi, hasil kedua penelitian tersebut memiliki temuan yang berbeda dengan penelitian ini dikarenakan ISO berpengaruh terhadap kinerja sumber daya manusia.

Penelitian yang lain seperti yang dilakukan Umiyati (2015) juga tidak sejalan dengan penelitian ini lantaran variabel yang dipasangkan tidak sama. Variabel yang dipasangkan Umiyati (2015) adalah implementasi ISO dan penyusunan anggaran. Sementara penelitian ini memasangkan variabel ISO 9001:2015, motivasi dan kompetensi. Umiyati (2015) hanya menggunakan beberapa klausul, sedangkan penelitian ini mengacu pada semua klausul yang ada, kecuali pada satu klausul khusus lantaran jauh dari objek yang diteliti.

Alasan ini tidak dapat peneliti yakini sebagai penyebab tidak berpengaruhnya ISO 9001:2015. Alasan lainnya, variabel yang dipasangkan Umiyati (2015) antara ISO dan penyusunan anggaran sasaran dokumennya hampir sama. Sementara antara SMM ISO 9001:2015, motivasi dan kompetensi tidak memiliki cakupan yang sama.

Berdasarkan sebaran kajian penelitian tentang pengaruh ISO 9001, diketahui bahwa sebanyak $65 \%$ penelitian yang tidak menggunakan variabel lainnya. Ada variabel lain yang juga diteliti di Perpustakaan Universitas Hasanuddin dapat menjadi alasan tidak berpengaruhnya ISO 9001:2015 terhadap kinerja pustakawan. Selanjutnya, apabila ditelaah dari segi orientasi, perpustakaan berorientasi non profit, dari segi administrasi perpustakaan lebih pada hal teknis berbeda dengan pendidikan sekolah. Apalagi perusahaan yang berorientasi profit di mana berlombalomba untuk memenuhi sertifikat ISO 9001 terutama pada produknya untuk mendapatkan eksistensi yang baik di mata konsumennya.

Kemudian berdasarkan sebaran kajian penelitian tentang pengaruh ISO 9001, diperoleh hasil bahwa indikator yang paling banyak digunakan untuk mengetahui pengaruh atau dampak ISO 9001 terhadap kinerja SDM adalah klausul SDM dalam ISO 9001:2008 atau operasional dalam ISO 9001:2015 sebanyak $31 \%$. Sementara penelitian ini menggunakan indikator berbagai klausul yang ada dalam SMM 9001:2015 di mana tingkat persentasenya sebanyak 15\%, masih berada jauh dari persentase indikator prinsip manajemen mutu yaitu $27 \%$.

Hal ini berarti indikator yang digunakan dapat menjadi alasan terhadap hasil penelitian yang diperoleh. Selanjutnya, terdapat indikator lainnya yang juga digunakan dalam meneliti pengaruh SMM ISO yaitu tahap perencanaan SMM ISO 9001 dengan persentase sekitar $8 \%$, pengendalian dokumen 4\%, siklus PDAC 4\%, dan indikator yang tidak termasuk dalam pedoman atau persyaratan ISO yaitu sekitar 3\%. Indikator-indikator tersebut juga dapat digunakan untuk lebih mengetahui lebih jauh pengaruh ada atau tidaknya pengaruh SMM ISO 9001:2015 terhadap kinerja pustakawan di Perpustakaan Universitas Hasanuddin 
Makassar.

Berdasarkan sebaran kajian penelitian tentang pengaruh ISO 9001 diperoleh bahwa objek penelitian yang paling banyak dipengaruhi ISO 9001 adalah yang bukan termasuk dalam kinerja SDM dengan persentase $25 \%$. Objek penelitian yang dimaksud seperti produk, kualitas lulusan perguruan tinggi, kepuasan pelanggan, mutu pendidikan, pembelajaran dan sebagainya. Selanjutnya, objek penelitian berikutnya yang paling berpengaruh adalah kinerja organisasi sebanyak 20\%, kinerja pegawai yang dapat disejajarkan dengan kinerja pustakawan berada pada persentase 15\%, kinerja guru $11 \%$, pelayanan $9 \%$, dan kinerja SDM yang paling banyak dipengaruhi adalah kinerja karyawan yaitu sebanyak 20\% sama dengan kinerja organisasi.

Pernyataan di atas juga diperkuat hasil wawancara dengan salah satu pustakawan Universitas Hasanuddin, sehingga objek penelitian ini dapat menjadi alasan tidak berpengaruhnya ISO 9001:2015 terhadap kinerja pustakawan. Selain itu, terkait penelitian ISO 9001:2015, di antara 98 penelitian terdapat 75 yang berpengaruh, 23 di antaranya tidak disebabkan oleh kurangnya kesadaran dan tanggung jawab akan sistem manajemen mutu bagi pegawai/karyawan, tidak melakukan komunikasi kebijakan mutu, variabel moderating yang digunakan, pelaksanaan prosedur yang kurang jelas, dan sumber daya manusia yang kurang.

Olehnya itu, perlu keterlibatan pustakawan secara intens dalam menerapkan sistem manajemen mutu, monitoring, dan evaluasi secara berkesinambungan yang dilakukan oleh pihak pimpinan Perpustakaan Universitas Hasanuddin tanpa menunggu tim audit ISO pusat.
Sebagaimana yang dijelaskan sebelumnya, hipotesis 2 diterima karena motivasi berpengaruh terhadap kinerja pustakawan Perpustakaan Universitas Hasanuddin. Dengan demikian, motivasi memiliki pengaruh positif yang signifikan terhadap kinerja pustakawan, sehingga apabila motivasi meningkat maka kinerja pustakawan juga akan meningkat.

Secara detail, kebutuhan pustakawan akan gaji yang wajar, kondisi kerja yang menyenangkan telah terpenuhi dengan baik. Sementara itu, kondisi kerja yang aman dan keamanan kerja telah terpenuhi. Peluang hubungan sosial dan semangat ke arah kerja sama juga telah terpenuhi.

Selanjutnya, pengakuan umum untuk kinerja yang baik dan jabatan pekerjaan yang terhormat telah terpenuhi dengan baik dengan memberikan penghargaan baik berupa insentif maupun penghargaan berprestasi. Hal itu dikarenakan setiap tahunnya diadakan lomba pustakawan berprestasi se-Universitas Hasanuddin sehingga mereka termotivasi untuk menjadi lebih baik. Sementara, peluang untuk maju dan memotivasi ke arah prestasi yang tinggi telah terpenuhi.

Indikator yang paling mendukung berpengaruhnya variabel terhadap kinerja pustakawan adalah indikator penghargaan dan aktualisasi diri. Hal ini berarti, Perpustakaan Universitas Hasanuddin sangat mendukung sumber daya manusia yang dimiliki untuk mengaktualisasi diri mereka. Temuan ini telah mendukung teori hierarki kebutuhan Maslow yaitu kebutuhan menjadi dasar untuk memotivasi sumber daya manusia pada suatu organisasi.

Sesuai dengan hasil uraian tersebut di atas, maka pustakawan perlu mengenali, memahami, dan memenuhi kebutuhan fisiologis, lingkungan kerja yang aman, 
perasaan diterima di tempat kerja, penghargaan terhadap sesama pustakawan, dan pengakuan terhadap potensi diri atau aktualisasi diri. Apabila semua hal tersebut telah tercukupi, maka motivasi pustakawan akan meningkat dan kinerja pun akan meningkat.

Penelitian ini juga mendukung temuan hasil penelitian terdahulu. Berdasarkan Octaviani (2015), kinerja pustakawan di BPA Provinsi Bali dipengaruhi oleh motivasi kerja. Begitu pula dengan penelitian Handayani (2015), di mana kinerja pustakawan Perpustakaan ITS Surabaya dipengaruhi oleh motivasi dan lingkungan kerja. Apabila motivasi pustakawan menurun maka kinerja pustakawan pun akan menurun.

Meski demikian, pihak yang berwenang dalam Perpustakaan Universitas Hasanuddin harus mempertahankan dan meningkatkan kenyamanan dalam bekerja bagi para pustakawan. Meski demikian, masih ada pustakawan yang merasa belum terpenuhi kebutuhan fisiologinya. Namun demikian, hasil observasi peneliti menemukan bahwa para pustakawan kurang bersemangat dalam bekerja sehingga dapat bernilai buruk terhadap kinerja mereka.

Berdasarkan hasil pengamatan peneliti, ditemukan juga hubungan personal antar pustakawan yang terlihat kurang baik pada beberapa orang. Tentu hal ini akan mengganggu aktivitas saat bekerja. Oleh karena itu, motivasi yang ada perlu lebih ditingkatkan kembali terutama pada lingkungan kerja yang memadai dan mampu meningkatkan komunikasi yang mengeratkan hubungan antar pustakawan.

Hipotesis ketiga juga telah terbukti dengan temuan kompetensi yang berpengaruh terhadap kinerja pustakawan Perpustakaan Universitas Hasanuddin. Hal ini disebabkan, kepala setiap unit adalah pustakawan yang terus mengembangkan karir sehingga dapat berdampak pada kompetensi bawahan. Apabila kompetensi meningkat maka kinerja pustakawan juga akan meningkat.

Berdasarkan temuan yang telah didapatkan, maka Perpustakaan Universitas Hasanuddin telah mampu merencanakan dan melaksanakan program perpustakaan, mengevaluasi program perpustakaan. Layanan jasa informasi perpustakaan telah diorganisasikan dengan baik dan teknologi informasi telah diterapkan dengan baik. Perpustakaan Universitas Hasanuddin telah menerapkan program literasi dengan baik dan melakukan promosi perpustakaan.

Selain itu, ada beberapa pustakawan yang bergabung dalam organisasi Ikatan Pustakawan Indonesia, pustakawan yang sudah memiliki sertifikasi, memiliki pengalaman yang luas, dan hampir semua unit dikepalai oleh pustakawan yang memiliki latar belakang pendidikan yang tinggi. Hal ini mampu meningkatkan kompetensi yang dimiliki setiap pustakawan. Pustakawan Perpustakaan Universitas Hasanuddin memiliki integritas dan etos kerja yang tinggi untuk membangun hubungan komunikasi dan sosial kemasyarakatan. Hal ini sesuai pendapat Kardi (2016) yaitu pustakawan yang memiliki integrasi tinggi terhadap pekerjaannya dan mengoptimalkan potensi yang melekat dalam diri individu akan dapat menunjang performa kerja yang baik.

Pustakawan telah mengembangkan sikap profesional dalam bekerja dengan cara mengembangkan ilmu lebih dalam, 
mengilhami etika profesi terutama kode etik pustakawan, menumbuhkan dan mengembangkan budaya minta baca. Hal ini pula diperkuat oleh hasil wawancara dengan responden dan beberapa informan yang menyatakan kompetensi pustakawan Perpustakaan Universitas Hasanuddin sudah cukup baik dan telah dibuktikan dengan hasil dokumentasi serta didukung oleh pernyataan Suwarno (2016) yaitu kompetensi yang baik akan menjadikan pustakawan sebagai pelaku kinerja yang unggul.

Oleh karena itu, penelitian yang dilakukan mendukung teori yang ada yaitu kompetensi mampu memberikan peningkatan hasil kerja pustakawan dengan mengembangkan unsur kompetensi sebagaimana yang tercantum dalam SKKNI Bidang Perpustakaan, yaitu kompetensi dasar atau umum, kompetensi inti dan kompetensi khusus. Penelitian ini juga didukung kajian-kajian penelitian terdahulu, seperti penelitian Diyah, and Permana (2012) yang menemukan bahwa kompetensi memengaruhi kinerja pustakawan Perpustakaan UNS. Adapun penelitian Pamungkas, Setyowati, and Hermintatik (2015), yang menyatakan bahwa kompetensi berpengaruh terhadap kinerja pustakawan di Perpustakaan Universitas Brawijaya.

Kompetensi yang tinggi harus dimiliki pustakawan agar kinerja yang dihasilkan juga semakin tinggi dan sebaliknya. Namun demikian, untuk meningkatkan kemampuan dan keterampilan pustakawan maka perlu meningkatkan kompetensi manajerialnya. Kompetensi yang dimiliki pustakawan bagian unit layanan juga perlu ditingkatkan, sehingga mempermudah pemustaka menelusur informasi yang ada.

Secara simultan, semua variabel bebas dapat berkontribusi dengan baik atau signifikan terhadap variabel terikat serta pengaruh yang diberikan bersifat positif. Maka hipotesis empat variabel telah terbukti. Oleh karena itu, apabila diuji secara bersama-sama variabel SMM ISO 9001:2015, motivasi, dan kompetensi maka dapat berpengaruh secara signifikan terhadap kinerja pustakawan. Hal ini berarti, semakin tinggi SMM ISO 9001:2015, motivasi, dan kompetensi, maka semakin tinggi pula kinerja Pustakawan Universitas Hasanuddin.

Oleh sebab itu, pihak Perpustakaan Universitas Hasanuddin harus memberikan perhatian terhadap perbaikan terus menerus guna memenuhi kebijakan mutu yang ada, meningkatkan motivasi dan kompetensi pustakawan guna mencapai tujuan perpustakaan.

Secara garis besar pustakawan telah mampu mengerjakan tugasnya dengan baik sebagai bentuk sikap warga aparatur negara dengan baik, lebih mengutamakan kepentingan kerja di atas kepentingan lainnya, mempunyai pengalaman luas sesuai bidang yang digeluti dan yang berhubungan, hasil kerja maksimal melebihi pencapaian yang diperoleh selama ini baik dari segi kuantitas maupun kualitas. Pustakawan telah menyelesaikan tugas secara disiplin waktu, berani bertindak dan bertanggung jawab atas tindakannya tersebut, dan menjadi pustakawan yang loyal terhadap pemimpinnya.

Pustakawan telah mengemban tugas dengan sebaik-baiknya dan tidak menyalahgunakan wewenang yang diberikan kepadanya telah terpenuhi. Pustakawan telah mampu saling menghargai dan bersikap terbuka terhadap keputusan yang disepakati secara mufakat walaupun tidak 
sependapat telah terpenuhi.

Pustakawan Perpustakaan Universitas Hasanuddin juga memiliki inisiatif untuk bekerja kreatif, memecahkan masalah dan mengambil keputusan, tetapi semua yang dilakukan tidak serta bertentangan dengan kebijakan yang ada. Pustakawan juga telah berusaha memberikan saran apabila diperlukan kepada kepala perpustakaan, baik diminta secara sukarela maupun tidak mengenai atau yang berhubungan dengan pelaksanaan tugas.

Pustakawan juga telah mampu mengemukakan pendapat dengan orang lain dan memberikan teladan yang baik telah terpenuhi. Tingkat pengaruh variabel SMM ISO 9001:2015, motivasi dan kompetensi adalah 79,5\% dianggap cukup kuat. Adapun sisanya sebanyak 20,5\% dipengaruhi oleh variabel lainnya seperti hasil wawancara yaitu standar kinerja pegawai atau tunjangan kinerja, disiplin kerja, stres, beban kerja dan lain sebagainya.

\section{SIMPULAN}

Penelitian ini tetap dapat dijadikan bahan rujukan untuk memaksimalkan klausul sumber daya manusia ISO 9001:2015 pada Perpustakaan Universitas Hasanuddin sebab ISO 9001:2015 tidak dapat berpengaruh secara parsial terhadap kinerja pustakawan. Sementara, variabel kompetensi dan motivasi justru memiliki pengaruh secara parsial terhadap kinerja pustakawan yang disebabkan oleh sikap pustakawan yang menjunjung tinggi motivasi dan pustakawan secara terus menerus dalam meningkatkan kompetensinya Selain itu, apabila diintegrasikan dengan motivasi dan kompetensi maka SMM ISO 9001:2015 secara simultan dapat memengaruhi kinerja pustakawan. Dengan kata lain, variabel SMM ISO 9001:2015 mengandung unsur yang terdapat dalam motivasi dan kompetensi sehingga dapat memengaruhi kinerja pustakawan secara bersama-sama. Sesudah penelitian ini, peneliti berencana meneliti mengenai sebaran penelitian tentang variabel yang memengaruhi kinerja pustakawan.

\section{DAFTAR PUSTAKA}

Abdullah, S., \& Sutanto, T. E. (2015). Statistika tanpa stress. Jakarta: TransMedia Pustaka.

Alfatih, M. I., \& Wijayanti, L. (2018). Leadership in the public library: Case study in tenteram city public library. Record and Library Journal, 3(1), 50-62. https:// doi.org/10.20473/rlj.V3I1.2017.50-62

Asmad, C. C., \& Mathar, T. (2015). Peran pustakawan dalam meningkatkan kinerja perpustakaan: Studi kasus di Perpustakaan MAN I Makassar). Khizanah Al-Hikmah: Jurnal Ilmu Perpustakaan, Informasi, Dan Kearsipan, $3(2)$, 101-111. https://doi.org/10.24252/kah.v3i2a1

Astuti, D., \& Ati, S. (2015). Pengaruh implementasi sistem manajemen mutu ISO 9001: 2008 terhadap peningkatan kualitas layanan di UPT Perpustakaan Politeknik Negeri Semarang. Ilmu Perpustakaan, 4(3), 3140. Retrieved from https:// ejournal3.undip.ac.id/index. php/jip/article/view/9722/9444

Azmar, N. J. (2015). Peran pustakawan dalam meningkatkan kualitas layanan di perpustakaan. Jurnal Iqra, 9(2), 223224. Retrieved from http://jurnal.uinsu.ac.id/index.php/ iqra/article/view/119/227

Daft, R. L. (2012). Era baru manajemen. 
Jakarta: Salemba Empat.

Diyah, K., \& Permana, A. (2012). Pengaruh kompetensi pustakawan terhadap kinerja perpustakaan di UPT Perpustakan Universitas Negeri Semarang. Jurnal Ilmu Perpustakaan, 1(1), 1-7. Retrieved from https:// ejournal3.undip.ac.id/index. php/jip/article/view/28/36

Fatma, R., Damayani, N. A., \& Rusmana, A. (2016). Kegiatan sanggar sastra Rumah Puisi Taufiq Ismail dalam mendukung perilaku menulis. Jurnal Kajian Informasi \& Perpustakaan, 4(1), 49-58.

https:// doi.org/10.24198/jkip.v4i1.11 630

Ghozali, I. (2011). Aplikasi analisis multivariat dengan program IBM SPSS 19. Semarang: Universitas Diponegoro.

Handayani, R. D. (2015). Pengaruh motivasi kerja dan lingkungan kerja terhadap kinerja karyawan Perpustakaan Institut Teknologi Sepuluh November (ITS) Surabaya (Skripsi) (Universitas Airlangga, Surabaya). Retrieved from http:/ / repository.unair.ac.id/17697/

Hs, L. (2009). Kamus kepustakawanan Indonesia. Yogyakarta: Pustaka Book.

Husna, J. (2018). Pengaruh perilaku asertif pustakawan dalam keberhasilan program liaison librarian di perpustakaan. Anuva, 2(4), 437-449. https://doi.org/10.14710/anuva.2.4.4 37-449

Indrasari, A. (2013). Penggunaan libqual + tm dalam evaluasi kualitas pelayanan Perpustakaan Universitas Setia Budi. Teknik Industri, 2(2), 117-124. Retrieved from http://ti.universitassuryadarma.ac.id /wpcontent/uploads/2016/01/JURNAL-
TI-VOL.-2-no.-2-November-2013-117124.pdf

Irsyada, B. D., \& Edwar, M. (2013). Pengaruh aspek sumberdaya manusia dan lingkungan kerja terhadap kinerja guru dalam penerapan sistem manajemen mutu ISO 9001:2008 di SMKN 2 Nganjuk. Jurnal Pendidikan Tata Niaga (JPTN), 1(3), 1-18. Retrieved from http://jurnalmahasiswa.unesa.ac.id/i ndex.php/jptn/article/view/4032/65 51

Jamaluddin. (2015). Pengaruh kelelahan kerja dan kecerdasan emosional terhadap kinerja Pustakawan di UPT Perpustakaan

Universitas Hasanuddin. Jupiter, 14(1), 42-51. Retrieved from http://journal.unhas.ac.id/index.php /jupiter/article/view/28/26

Kardi, K. (2016). Development of library systems management (delsma): Program benchmarking untuk peningkatan mutu perpustakaan perguruan tinggi keagamaan Islam (PTKI). Libraria: Jurnal Perpustakaan, 4(1), 181-206. https://doi.org/10.21043/libraria.v4i 1.1242

Levine, D., \& Michael, T. (2010). Quality management and job quality: How the ISO 9001 standard management systems affect employees and employers. Management Science, 56(6), 978-996.

https://doi.org/10.1287/mnsc.1100.1 159

Mayora, H., \& Nelisa, M. (2013). Strategi peningkatan pemanfaatan perpustakaan di Perpustakaan Khusus Sekretariat DPRD Provinsi Sumatera Barat. Ilmu Informasi Perpustakaan Dan Kearsipan, 2(1), 380- 
388. https:// doi.org/10.24036/23460934

Muhammad, I. N., Komariah, N., \& Kurniasih, N. (2019). Tindakan vandalisme di Perpustakaan Fakultas Ilmu Komunikasi Universitas Padjadjaran. Jurnal Kajian Informasi $\mathcal{E}$ Perpustakaan, 7(1), 81-94. https://doi.org/10.24198/jkip.v7i1.17 757

Nashihuddin, W., \& Aulianto, D. R. (2015). Strategi peningkatan kompetensi dan profesionalisme pustakawan di perpustakaan khusus (Strategy for improving competence and professionalism of librarian in special library). Perpustakaan Pertanian, 24(2), 51-58. Retrieved from http:/ / repository.pertanian.go.id/bit stream/handle/123456789/2213/STR ATEGI PENINGKATAN

KOMPETENSI

DAN

PROFESIONALISME

PUSTAKAWAN

DI

PERPUSTAKAAN

KHUSUS.pdf?sequence $=1$ \&is Allowed $=\mathrm{y}$

Nurjannah. (2016). Kompetensi pustakawan di era informasi global: Apa dan bagaimana? Libraria, 5(1), 117. Retrieved from https:/ /libraria.fpptijateng.or.id/index.php/lib/article/vi ew/16/12

Octaviani, N. P. N. (2015). Pengaruh motivasi kerja terhadap kinerja pustakawan di Badan Perpustakaan dan Arsip Provinsi Bali tahun 2015. Jurnal Ilmiah D3 Perpustakaan, 1(1), 111. Retrieved from https:/ / ojs.unud.ac.id/index.php/d3 perpus/article/download/14361/987 0

Pamungkas, L. D., Setyowati, E., \& H.
(2015). Pengaruh kompetensi pustakawan terhadap prestasi kerja: Studi pada Perpustakaan Universitas Brawijaya. Jurnal Administrasi Publik (JAP), 3(5), 739-744. Retrieved from http://administrasipublik.studentjou rnal.ub.ac.id/index.php/jap/search/ advancedResults

Rahmawaty, P. (2014). Dampak penerapan sistem manajemen mutu ISO 9001: 2000 terhadap kinerja organisasi: Studi kasus pada Fakultas Ilmu Sosial dan Ekonomi Universitas Negeri Yogyakarta. Retrieved February 20, 2019, from http://staff.uny.ac.id/ website:

http://staff.uny.ac.id/sites/default/f iles/penelitian/Penny Rahmawaty, M.Si./Artikel Dampak Penerapan Sistem Manajemen Mutu ISO 9001.pdf

Risparyanto, A. (2017). Pengaruh motivasi dan kompetensi terhadap kualitas layanan pustakawan. Berkala Ilmu Perpustakaan Dan Informasi, 13(1), 111.

https://doi.org/10.22146/bip.26202

Sampe, M. S. (2014). Pengaruh kompetensi terhadap kinerja Pustakawan Universitas Hasanuddin. Jupiter, 13(2), 22-25. Retrieved from http://journal.unhas.ac.id/index.php /jupiter/article/view/1643/931

Sindhuwinata, O. E., \& F. (2016). Perancangan SMM ISO 9001:2015: Studi kasus. Jurnal Titra, 4(2), 183190.

Retrieved from http://publication.petra.ac.id/index. php/teknik-

industri/article/view/4590/4207

Sugiyono. (2013). Metode penelitian kuantitatif, kualitatif dan RED. Bandung: Alfabeta.

Supriyadi, E. (2012). Pengaruh penerapan 
sistem manajemen mutu ISO 9001: 2008 terhadap kinerja guru di SMK Negeri 1 Sedayu Bantul (Skripsi). Universitas Negeri Yogyakarta, Yogyakarta, Yogyakarta.

Suwarno, W. (2016). Mengembangkan SDM perpustakaan dalam rangka menuju world class university. Libraria, $\quad 4(1)$, $\quad$ 105-126. https://doi.org/10.21043/libraria.v4i 1.1241

Umiyati. (2015). Pengaruh sistem manajemen mutu ISO 9001: 2008 dan partisipasi penyusunan anggaran terhadap kinerja manajerial. Etikonomi: Jurnal Ekonomi, 14(1), 87112. https:

//doi.org/10.15408/etk.v14i1.2265 
